\title{
ZINC EXPOSURE FOR FEMALE WORKERS IN A GALVANIZING PLANT IN NORTHERN ITALY
}

\author{
MATTEO RICCÒ ${ }^{1}$, SILVIA CATTANI ${ }^{2}$, and CARLO SIGNORELLI ${ }^{3}$ \\ ${ }^{1}$ Provincial Agency for Health Services of the Autonomous Province of Trento, Trento, Italy \\ Department of Prevention \\ ${ }^{2}$ University of Parma, Parma, Italy \\ Department of Clinical Surgery, General Surgery and Surgical Therapy, School of Nursing Sciences \\ ${ }^{3}$ University of Parma, Parma, Italy \\ Department of Biomedical, Biotechnological, and Translational Sciences (SBiBiT)
}

\begin{abstract}
Objectives: Very little is known regarding the toxicokinetics of inhaled zinc, in particular in the case of female workers and for modern, low exposure settings. Our aim is to evaluate the relationship of external zinc levels to those of serum and urine for female workers. Material and Methods: Eleven female workers (age: $41.7 \pm 8$ years old, body mass index (BMI): $\left.23.5 \pm 4.2 \mathrm{~kg} / \mathrm{m}^{2}\right)$ in a galvanizing plant were investigated. Exposure assessment consisted of personal/environmental air samples, and measurement of zinc in serum (collected at the end of first shift of the working week (T1)) and urine, collected before the first shift of the working week (T0), T1 and at the end of the last shift of the working week (T2). Results: Both environmental and personal air samplings for zinc and zinc compounds were below the recommended by the German Research Foundation (Deutsche Forschungsgemeinschaft - DFG) limit values of $2 \mathrm{mg} / \mathrm{m}^{3}\left(7.34 \pm 2.8 \mu \mathrm{g} / \mathrm{m}^{3}\right.$ and $8.31 \pm 2.4 \mu \mathrm{g} / \mathrm{m}^{3}$, respectively). Serum $(118.6 \pm 20.9 \mu \mathrm{g} / \mathrm{dl})$ and urine zinc levels were within reference values for female Italian subjects: the latter increased from $56.4 \pm 33.5 \mu \mathrm{g} / \mathrm{dl}$ at T0, to $59.8 \pm 37.0 \mu \mathrm{g} / \mathrm{dl}$ at T1, and ultimately $65.4 \pm 34.4 \mu \mathrm{g} / \mathrm{dl}$ at T2, but no significant trend was found. End of shift (Spearman's correlation coefficient $\mathrm{p}$ value $=0.027$ ) and differential excretion of urinary zinc (both: T0 vs. T1 and T0 vs. T2) were correlated with airborne zinc concentration ( $\mathrm{p}=0.002$ and 0.006 , respectively). Conclusions: In general, our data suggests that urine may be a useful medium also for female in order to assess zinc exposure. Further studies are required in order to evaluate whether differential excretion may be useful for the biomonitoring of zinc exposure in the workplaces also for male workers. Int J Occup Med Environ Health 2018;31(1):113-124
\end{abstract}

Key words:

Biological monitoring, Zinc, Metal fume fever, Galvanization, Heavy-metal interaction, Electrogalvaning

\section{INTRODUCTION}

Galvanization is the process of coating steel, or cast iron pieces of any size, weight, shape, and complexity with zinc $(\mathrm{Zn})$, allowing protection against corrosion [1]. Zinc coating may be obtained by simple immersion in a plating bath or through electrolytic galvanization (electrogalvaning). Electrogalvaning has experienced a sustained industrial success since the early 80s, and nowadays around 5 million tons/year of zinc are worldwide used in this process [2]. In electrogalvaning, a current of electricity runs through a saline/zinc solution, and the zinc coating is obtained through the dissolution of the sacrificial zinc anode on the iron/steel conductor [3]. As the composition of the plating bath depends on the processes

Received: December 26, 2015. Accepted: December 4, 2016.

Corresponding author: M. Riccò, Provincial Agency for Health Services of the Autonomous Province of Trento, Department of Prevention, Operative Unit of Occupational Health and Safety on the Workplaces, Viale Verona SNC, Palazzina A, 38123 Trento, Italy (e-mail: matteo.ricco@apss.tn.it, mricco2000@gmail.com). 
employed, particulate and vapor emissions are also quite variable.

For example, in alkaline non-cyanide zinc baths, the solution contains zinc metal (6-22.5 g/l) and sodium hydroxide $(74.9-149.8 \mathrm{~g} / \mathrm{l})$ at $\mathrm{pH}=12-13$ whereas acid baths contain zinc metal (15-30 g/l) and ammonium chloride (120-180 g/l) at $\mathrm{pH}=5-6$ or zinc metal (22-38 g/l) with potassium chloride (185-225 g/l) and boric acid (22-38 g/l) at $\mathrm{pH}=5-5.5$. Since these processes are operated at temperatures ranging from about $15-45^{\circ} \mathrm{C}$, occupational exposures to toxic intermediates have been defined as relatively low $[3,4]$.

Unfortunately, data about workplace exposures to zinc and/or its compounds is lacking, and this shortfall also involves international regulations and occupational health and safety guidelines [4]. For instance, available exposure limit values from the American Conference of Governmental Industrial Hygienists (ACGIH) focus on zinc oxide $(\mathrm{ZnO})$, with a threshold limit value - time weighted average (TLV-TWA) (i.e., the level of chemical substance to which a worker may be exposed on the basis of a $8 \mathrm{~h} /$ day, $40 \mathrm{~h} /$ week work schedule without adverse effects) of $2 \mathrm{mg} / \mathrm{m}^{3}$ for respirable fraction whereas a limit value for zinc and compound has recently been identified by the German Research Foundation (Deutsche Forschungsgemeinschaft - DFG) in $0.1 \mathrm{mg} / \mathrm{m}^{3}$ for respirable fraction and $2 \mathrm{mg} / \mathrm{m}^{3}$ for inhalable fraction $[5,6]$.

Such exposure limits were originally defined in order to prevent the "metal fume fever" (MFF), a self-limited but uncomfortable flu-like syndrome that typically follows inhalation of $\mathrm{Zn} / \mathrm{ZnO}$ in a form of finely dispersed particulate matter, even at doses that do not cause systemic reactions, and in particular for concentrations $>500 \mu \mathrm{g} / \mathrm{m}^{3}[7]$. "Metal fume fever" usually onsets with an unusual, metallic taste in the mouth accompanied by dryness and irritation of the throat, followed by a variety of systemic symptoms (i.e., fever, chills, dyspnea, muscle soreness, nausea, and fatigue) [8-12].
Primary pulmonary involvement is characterized by reduced lung volumes and a decreased diffusing capacity of carbon monoxide [11-13]. Signs/symptoms usually occur within 4-8 $\mathrm{h}$ after exposure to $\mathrm{Zn} / \mathrm{ZnO}$ fumes and persist for 24-48 h. An increased tolerance develops within repeated exposures but it is lost after a brief period without exposure: as MFF symptoms are most commonly reported at the beginning of the working week and after holidays, it is otherwise called "Monday morning syndrome" [14]. Zinc exposure in the general population occurs primarily through ingestion, with an average intake of 5.2-16.2 mg/day. Following the absorption through the gastrointestinal tract, the highest concentrations have been found in bone, muscle, prostate, liver and kidneys [15-17]. Liver, pancreas, bone, kidney and muscle are the major tissue storage sites, and less than $10 \%$ of the body's total zinc, equivalent to a $10-18 \mu \mathrm{M}$ concentration, is readily exchanged with plasma [18-21]. Under normal physiological conditions, blood zinc is chiefly localized within erythrocytes, and the plasma/ serum zinc level is around $100 \mu \mathrm{g} / \mathrm{dl}$ : the available research has recently identified - in 80-160 $\mu \mathrm{g} / \mathrm{dl}$ - the normal reference values for Italian non-occupationally-exposed subjects whereas previously estimated values had suggested a range of $81.2 \pm 13.1 \mu \mathrm{g} / \mathrm{dl}$ for general Italian population $(75.5 \pm 12.3 \mu \mathrm{g} / \mathrm{dl}$ in female subjects) [22,23].

Around $98 \%$ of serum zinc is bound to proteins (in particular: $85 \%$ to albumin, $12 \%$ to $\alpha_{2}$-macroglobulin) whereas the remainder $2 \%$ is bound to ultrafiltereable small organic molecules such as citrate and amino-acids. As the latter is only excreted in the urine, usual urinary levels range from $25 \mu \mathrm{g} / \mathrm{dl}$ to $65 \mu \mathrm{g} / \mathrm{dl}$ (or $0.5 \mathrm{mg} / \mathrm{g}$ creatinine) [20,21,24-27].

Toxicokinetics of inhaled zinc still remains largely undefined. Early studies on animals exposed to airborne $\mathrm{ZnO}$ found increased zinc concentration in the gallbladder, kidney and pancreas [28] whereas elevated levels of zinc had been reported in the urine of workers exposed to fumes containing $\mathrm{ZnO}[14,29]$. Unfortunately, available studies 
did not provide estimates of the relationship between zinc exposure levels and the levels of zinc in biological fluids but collectively confirmed that zinc was absorbed following inhalation exposure [14,29-31].

However this data should be interpreted cautiously for several reasons. First at all, much of our current understanding of zinc inhalatory toxicokinetics for human beings is based on studies performed on workers exposed to high or relatively high levels of $\mathrm{ZnO}[1,14,29]$ or for subjects hospitalized as a consequence of MFF $[12,13,26]$. Moreover, previous occupational studies about the toxicokinetics of zinc in electrogalvaning had focused almost exclusively on men $[1,14,29,32]$. Although women may differ from men in many ways that may be relevant to the zinc exposure assessment, including physiology (i.e., absorption, distribution, metabolism and excretion of xenobiotics) and behavior (e.g., risk tolerance), very little is known about occupational exposure to zinc in the case of females (apart from possible effects on the fetus) [32].

Our aims therefore are:

- to gain further insight into the relationship of external zinc levels to those of serum and urine in modern lowexposure settings where the presumptive risk of MFF is also reduced;

- to evaluate the usability of urine/serum zinc assessment for female workers;

- to define the time trend of zinc urine excretion during the working week, in order to obtain a better definition of the relationship between inhalation absorption and urinary excretion.

\section{MATERIAL AND METHODS}

\section{Study population}

The study was carried out in a small electrogalvanization plant in Northern Italy in June 2013. At the time the study was performed, a total of 16 workers were employed: 13 of them were directly involved in the electroplating procedures, including 11 females. All female workers were even- tually asked to participate in this study. The working day was organized into two 8-h shifts beginning at 6:00 a.m., and the employed from the production line rotated through all the tasks required by electroplating processes (i.e., conduction of the plating baths, preliminary brushing of the items to be plated, their positioning on the zinc plating ranks, and eventually their recovery and shipment).

\section{Investigations}

Clinical assessment was performed at the beginning of the working week (T0), requiring the collection of the personal clinical history, and a complete physical examination performed by an occupational physician. Recalled data included personal clinical history, current and past (i.e., previous 12 month) systemic and respiratory symptoms in relation to work (i.e., fever and/or chills in relation to work; nausea, dyspnea, cough, headache, sweet or metallic taste, throat irritation, or fatigue), and was performed through a modified version of the European Coal and Steel Community (ECSC) respiratory questionnaire [33].

Pulmonary function tests were performed according to the American Thoracic Society standards for occupational medicine studies before the beginning of the first working shift (T0), and repeated at its end (T1) [34], including measurement of forced vital capacity (FVC), forced expiratory volume in $1 \mathrm{~s}\left(\mathrm{FEV}_{1}\right)$, Tiffeneau index $\left(\mathrm{FEV}_{1} / \mathrm{FVC}\right)$, forced expiratory flow at $25-75 \%$ of the pulmonary volume $\left(\mathrm{FEF}_{25-75 \%}\right)$ and peak expiratory flow (PEF). As all subjects were of Caucasian ethnicity, reference values proposed by the ECSC (1983) were applied [35,36].

Airborne zinc concentrations were measured according to the standards set out by the United States Occupational Safety and Health Administration (OSHA), method 121 for metal and metalloid particulates in the workplace atmospheres. Exposure assessment was performed on the first the day of the working week and consisted of external sampling through an environmental (air flow: $2.5 \mathrm{l} / \mathrm{s}$ ) and personal air sampler (air flow: $0.5 \mathrm{l} / \mathrm{s}$ ). 
Samples were collected on mixed cellulose ester filters with a pore size of $0.45 \mu \mathrm{m}$ in preloaded closed-faced $37 \mathrm{~mm}$ diameter cassettes and then analyzed through flame atomic absorption spectrometry [37]. The personal sampler allowed for full-shift monitoring for the participants during the first day of the working week, all rotating throughout the working tasks. and required 3 sampling points for the following working areas: loading of zinc plating ranks; control station of the plating bath; area of recovery and shipment of plating ranks.

Airborne dusts were sampled in the same working environments by means of a direct reading instrument (Aerocet 531 Particulate Monitor, Met One Instruments Inc., USA). A total of 8 samples were taken for every site, with a continuous sampling time of $2 \mathrm{~min} / \mathrm{sample}$. Results were expressed in terms of the concentration $\left(\mathrm{mg} / \mathrm{m}^{3}\right)$ for particulate matter with aerodynamic caliber having aerodynamic diameter $<10 \mu \mathrm{m}$.

Venous blood samples $(3-5 \mathrm{ml})$ were collected at $\mathrm{T} 1 \mathrm{using}$ metal-free vacutainer tubes (Becton Dickinson, Rutherford, NJ, USA) containing $>1.5 \mu \mathrm{g}$ of di-potassium salt of ethylenediaminetetraacetic acid ( $\mathrm{K}_{2}$-EDTA)/ml. After the collection, the whole blood sample was thoroughly mixed and transferred to a storage tube at $-4^{\circ} \mathrm{C}$ until further treatment. Blood sampling ultimately consisted of serum zinc measurement (values were expressed in $\mu \mathrm{g} / \mathrm{dl}$ ), performed through flame atomic spectrometry, having detection limit of $0.36 \mu \mathrm{g} / \mathrm{dl}$, and a complete blood count.

Urine samples were collected at $\mathrm{T} 0$ and $\mathrm{T} 1$, with a further sample collected at the end of the working week (T2). The urinary samples were collected in polycarbonate bottles and stored at $-4^{\circ} \mathrm{C}$. Measurement of zinc was performed using flame atomic spectrometry. All urine values were presented as $\mu \mathrm{g} / \mathrm{dl}$.

\section{Statistics}

Continuous variables had been preliminarily evaluated through D'Agostino-Pearson omnibus normality test in order to assess whether their values had a Gaussian distribution. For $\mathrm{p}$ values $<0.100$, a non-Gaussian distribution was assumed. Gaussian-distributed variables were compared through the Student's t-test or ANOVA when appropriate. Non-Gaussian distributed variables were evaluated through Wilcoxon matched-pairs signed rank test for paired variables whereas multiple comparisons (T0 vs. T1 vs. T2) were performed by means of Friedman test for repeated measures [38] and Dunn's multiple comparison test.

Similarly, non-parametric methods were applied to examine the relationship between zinc measured in air by means of the personal sampler, serum, and urine using Spearman's rank correlation method. In all cases, a p value $<0.05$ was considered statistically significant. Data was analyzed using software packages SPSS 22.0 (SPSS Inc., IBM) and GraphPad Prism version 6.0h for Macintosh (GraphPad Software, La Jolla California, USA).

\section{Ethics}

The study was performed as a part of the compulsory health assessment in the workplace (Italian Legislative Decree No. 81, April 9, 2008) [39]. All procedures were performed only in order to fully assess the clinical status and the fitness to work of the workers, and would have been performed even without the conduction of the study. Therefore, no preliminary evaluation by the Ethical Committee was reputed necessary. However, as clinical and personal data had been collected and elaborated, all participants gave their written consent and subjects refusing their consent were excluded from the study population.

\section{RESULTS}

\section{Clinical assessment}

Mean age of participants was $41.7 \pm 8$ years old, with a mean working history of $10.4 \pm 3.4$ years and a body mass index of $23.5 \pm 5.2 \mathrm{~kg} / \mathrm{m}^{2}$. All participants were of Caucasian ethnicity, and none of them was pregnant at 
the time of the survey, neither had pregnancies in the previous 9 months. At the time of the survey, none of the participants was taking any medication (including oral contraceptive) or was self-declared as an active smoker, but 2 workers $(18.2 \%)$ were previous smokers. None of them was required to respiratory personal protective equipment during the working hours. All collected clinical histories were negative for previous respiratory disorders or for gastrointestinal surgery requiring either diversions or excisions.

All subjects were asymptomatic at the time of the survey but reported at least one episode associated with one or more of the symptoms associated with MFF in the previous 12 months, and in particular: nausea $(\mathrm{N}=2,18.2 \%)$, dyspnea $(\mathrm{N}=1,9.1 \%)$, cough $(\mathrm{N}=3,27.3 \%)$, headache $(\mathrm{N}=3,27.3 \%)$, sweet or metallic taste $(\mathrm{N}=2,18.2 \%)$, throat irritation ( $\mathrm{N}=1,9.1 \%)$, fatigue $(\mathrm{N}=4,36.4 \%)$, or muscle cramp ( $\mathrm{N}=3,27.3 \%)$ whereas no participant referred to fever and/or chills in relation to the working shift. However, a distinctive time trend was not identified. Neither medical examinations nor laboratory exams were ultimately suggestive for MFF. In particular, both post- shift white cell count (mean of $7.18 \pm 2.2 \times 10^{9}$ cells/l) and hemoglobin concentration $(13.9 \pm 1.5 \mathrm{~g} / \mathrm{dl})$ were in normality range. With respect to pulmonary function tests, no significant cross-shift differences were identified (Table 1).

\section{Exposure assessment}

Results of the exposure assessment are presented in the Table 2. More specifically, airborne zinc concentration was $7.34 \pm 2.8 \mu \mathrm{g} / \mathrm{m}^{3}$ at personal sampling, and $8.31 \pm 2.4 \mu \mathrm{g} / \mathrm{m}^{3}$ at environmental sampling (Student's t test for unpaired data, $\mathrm{p}$ value $=0.381$ ), and environmental sampling identified an airborne of $1.58 \pm 0.34 \mathrm{mg} / \mathrm{m}^{3}$ for particles having aerodynamic diameter $<10 \mu \mathrm{m}$.

Mean urinary zinc concentration was $56.4 \pm 33.5 \mu \mathrm{g} / \mathrm{dl}$ at $\mathrm{T} 0$, increasing to $59.8 \pm 37.0 \mu \mathrm{g} / \mathrm{dl}$ at $\mathrm{T} 1(+6.1 \%$, range: $-73.3-148.6 \%)$, and ultimately $65.4 \pm 34.4 \mu \mathrm{g} / \mathrm{dl}$ at $\mathrm{T} 2(+9.3 \%$, range from -5.7 to $-125.9 \%$ compared to $\mathrm{T} 1$ and +15.9 , range from +83.3 to $+237.2 \%$ compared to T0) but no significant trend was identified (Friedman p value $>0.10$ ) (Figure 1). A statistically significant positive correlation was found between air sampling and urinary zinc measured at T1 (correlation coef-

Table 1. Pulmonary function tests performed at different sampling time for the female galvanizing plant workers $(\mathrm{N}=11)$

\begin{tabular}{|c|c|c|c|}
\hline \multirow{2}{*}{ Parameter } & \multicolumn{2}{|c|}{$\begin{array}{l}\text { Pulmonary function test }{ }^{\mathrm{a}} \\
\text { [\% of predicted value] } \\
(\mathrm{M} \pm \mathrm{SD})\end{array}$} & \multirow{2}{*}{$\mathrm{p}^{\mathrm{b}}$} \\
\hline & $\begin{array}{l}\text { before the first shift } \\
\text { of the working week } \\
\text { (T0) }\end{array}$ & $\begin{array}{l}\text { end of the first shift } \\
\text { of the working week } \\
\text { (T1) }\end{array}$ & \\
\hline FVC & $90.1 \pm 5.3$ & $91.1 \pm 4.2$ & $>0.5$ \\
\hline $\mathrm{FEV}_{1}$ & $89.9 \pm 5.7$ & $90.6 \pm 4.9$ & $>0.5$ \\
\hline $\mathrm{FEV}_{1} / \mathrm{FVC}$ & $79.8 \pm 2.5$ & $80.3 \pm 1.8$ & $>0.5$ \\
\hline PEF & $81.6 \pm 4.3$ & $81.4 \pm 1.9$ & $>0.5$ \\
\hline $\mathrm{FEF}_{25-75 \%}$ & $76.4 \pm 4.6$ & $77.5 \pm 1.3$ & $>0.5$ \\
\hline
\end{tabular}

FVC - forced vital capacity; $\mathrm{FEV}_{1}$ - forced expiratory volume in $1 \mathrm{~s} ; \mathrm{FEV}_{1} / \mathrm{FVC}$ - Tiffeneau index; PEF - peak expiratory flow; $\mathrm{FEF}_{25-75 \%}-$ forced expiratory flow at $25-75 \%$ of the pulmonary volume.

$\mathrm{M}$ - mean; SD - standard deviation.

${ }^{a}$ Spirometry was performed according to American Thoracic Society standards [34].

${ }^{\mathrm{b}}$ Wilcoxon matched-pairs signed rank test. 
Table 2. Zinc exposure assessment for the 11 female galvanizing plant workers

\begin{tabular}{lcc}
\hline & \multicolumn{2}{c}{ Zinc exposure } \\
\cline { 2 - 3 } & Sample source & range \\
\hline Sampler $\left[\mu \mathrm{g} / \mathrm{m}^{3}\right]$ & & $4.3-11.9$ \\
$\quad$ personal & $8.34 \pm 2.8$ & $4.3-12.1$ \\
$\quad$ environmental & $118.6 \pm 20.9$ & $97.0-156.0$ \\
Serum $[\mu \mathrm{g} / \mathrm{dl}]^{\mathrm{a}}$ & & \\
Urine $[\mu \mathrm{g} / \mathrm{dl}]^{\mathrm{b}}$ & $56.4 \pm 33.5$ & $22.5-118.6$ \\
$\quad$ before the first shift of the working week (T0) & $59.8 \pm 36.9$ & $14.7-151.8$ \\
$\quad$ end of the first shift of the working week (T1) & $65.4 \pm 34.4$ & $27.3-143.2$ \\
\hline end of the last shift of the working week (T2) & & \\
\hline
\end{tabular}

a Blood samples were collected at T1.

${ }^{\mathrm{b}}$ Urine samples were collected at $\mathrm{T} 0$ and $\mathrm{T} 1$, with a further sample collected at $\mathrm{T} 2$.

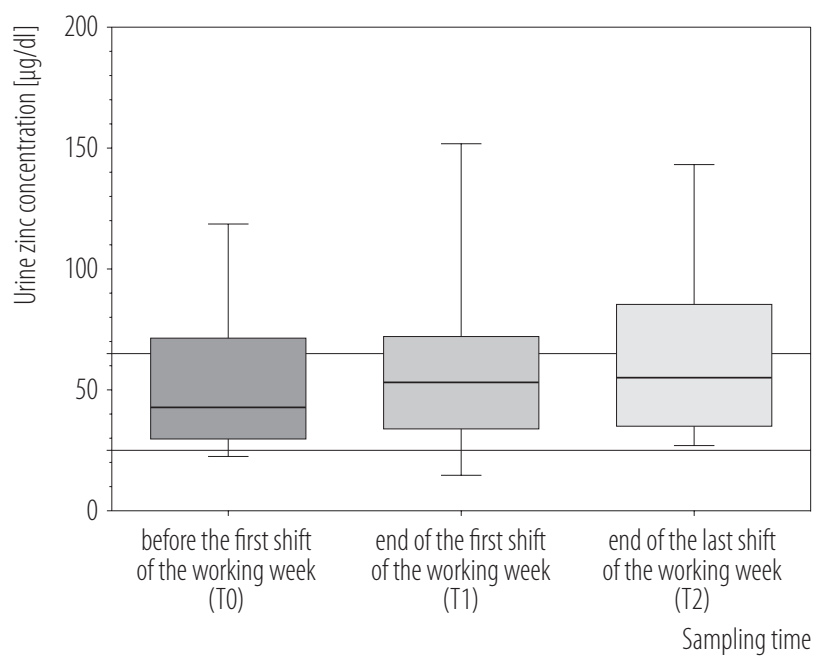

Reference values for Italian population (dotted lines): 25-65 $\mu \mathrm{g} / \mathrm{dl}$.

Fig. 1. Urinary excretion of zinc at 3 sampling times for female galvanizing plant workers $(\mathrm{N}=11)$

ficient $=0.673 ; \mathrm{p}$ value $=0.027)$ whereas no correlation was identified at T2 (correlation coefficient $=0.455$; $\mathrm{p}$ value $=0.164)$ (Figure 2$)$.

Differential excretion of urinary zinc for T0 vs. T1 was $3.42 \pm 33.4 \mu \mathrm{g} / \mathrm{dl}$ (range: $-62.8-53.5$ ) and $8.96 \pm 22.18 \mu \mathrm{g} / \mathrm{dl}$ (range: -21.8-49.4) for T0 vs. T2. A significant correlation with the external sampling was identified for T0 vs. T1 (Spearman's correlation coefficient $=0.836 ; \mathrm{p}$ val- ue $=0.002)$ and T0 vs. T2 (Spearman's correlation coefficient $=0.791 ; p$ value $=0.006)($ Figure 3$)$.

Mean serum zinc concentration at the end of $\mathrm{T} 1$ was $118.6 \pm 20.9 \mu \mathrm{g} / \mathrm{dl}$, with a range of $97-156 \mu \mathrm{g} / \mathrm{dl}$, being not significantly correlated with external sampling, as determined by means of the personal sampler (Spearman's correlation coefficient $=-0.082$; $\mathrm{p}$ value $=0.818)$. Similarly no significant correlation was found with white blood cell count (Spearman's correlation coefficient $=0.269$; $\mathrm{p}$ value $=0.420$ ) or hemoglobin (Spearman's correlation coefficient $=0.219 ; \mathrm{p}$ value $=0.514)$. Moreover, blood zinc concentration was not significantly correlated neither with T1 (Spearman's correlation coefficient $=0.009$; $\mathrm{p}$ value $=0.990)$ nor T2 urinary values (Spearman's correlation coefficient $=0.054 ;$ value $=0.881$ )

\section{DISCUSSION}

The National Institute for Occupational Safety and Health (NIOSH) has estimated that about 50000 workers worldwide are exposed to zinc fumes in foundries, during welding of galvanized materials, soldering or oxygen cutting of brass or galvanized metals, or in galvanizing processes [31]. However, no quantitative data exists about the systemic availability of zinc after inhala- 

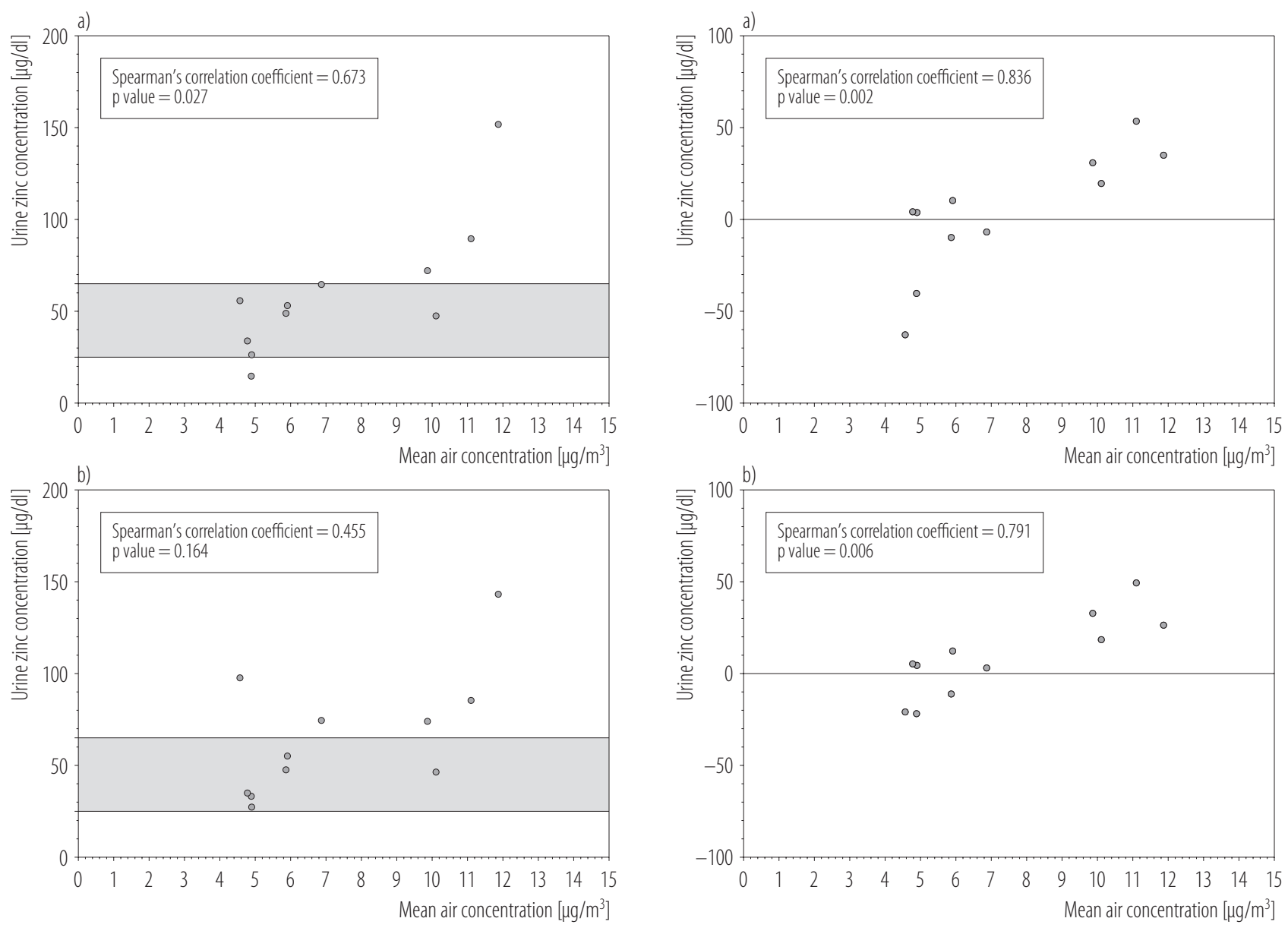

Reference values for Italian population (dotted lines): $25-65 \mu \mathrm{g} / \mathrm{dl}$. $\mathrm{T} 1$ - end of the first shift of the working week; T2 - end of the last shift of the working week.

Fig. 2. Correlation between urine zinc values and respective results of the external sampling as determined by personal samplers: a) T1, b) T2 in the study of female galvanizing plant workers $(\mathrm{N}=11)$

tion, neither for humans nor animals. Moreover, available observational data derives from settings with high or relatively high levels of $\mathrm{Zn} / \mathrm{ZnO}$ (e.g., foundries, high temperature plating bath, etc.) [1,14,29] or subjects hospitalized as a consequence of MFF, essentially male subjects $[11,13,14]$.

In this study, we have assessed zinc serum and urinary levels for female workers operating a modern electrogalvaning plant, where lower temperature of plating baths is

T0 - before the first shift of the working week; T1 - end of the first shift of the working week; T2 - end of the last shift of the working week.

Fig. 3. Differential excretion of zinc against mean air zinc, assessed for a) T0 vs. $\mathrm{T} 1$ and b) T0 vs. T2 in the study of female galvanizing plant workers $(\mathrm{N}=11)$

associated with a reduced production of zinc fumes and zinc-laden suspended particles, resulting in seemingly low exposure to airborne zinc [3,4,31]. Actually, external levels of zinc, as assessed by means of environmental and personal samplers, were ultimately well below the limit values suggested by the DFG for airborne zinc and zinc compound (i.e., $0.1 \mathrm{mg} / \mathrm{m}^{3}$ for respirable fraction and $2 \mathrm{mg} / \mathrm{m}^{3}$ for inhalable fraction).

Biological indices were also comparable to reference values for urine and serum zinc in Italian female popu- 
lation $[4-6,22,23]$ as well as to estimates from previous studies performed in workers having significantly higher occupational exposures $[1,14,29,40]$. Even though neither exposure data nor the gender composition of the sample was provided, our data was somehow consistent with a study performed in early 1980s on 123 Italian workers from 7 industrial plants performing zinc plating through high temperature processes (i.e., plasmatic levels of $\mathrm{Zn}$ having a range of 94-104 $\mu \mathrm{g} / \mathrm{dl}$; and urinary excretion ranging from $59.5 \mu \mathrm{g} / \mathrm{dl}$ to $92 \mu \mathrm{g} / \mathrm{dl}$ ) [41].

Clinical assessment was consistent with a reduced occupational exposure, as personal histories, physical examination, and more specifically respiratory function tests were negative for the both acute and chronic effects, as reassured by the stable cross-shift assessment. In effect, zinc compounds are well known respiratory irritants, both in short- and in long-term [5,6,10,11,41]. The DFG limit values of $2 \mathrm{mg} / \mathrm{m}^{3}$, similarly to ACGIH TLV-TWA for $\mathrm{ZnO}$, were specifically intended to be protective for upper airways, ultimately avoiding MFF for exposed workers $[5,6,10,11,31]$, but several studies suggested that lower chronic occupational exposures to zinc and $\mathrm{ZnO}$ might ultimately elicit long-term lung function changes [29,41]. Similar remarks may be drawn from the blood analyses. On the one hand, mean white blood cell count was within the normality range, and no significant correlation was identified with serum or urinary levels of zinc, ultimately ruling out an acute inflammatory effect elicited by airborne zinc and zinc compounds [11-13,28,30]. On the other hand, hemoglobin concentrations were in the normality range for Italian female population, implying no significant effect on the iron metabolism, as suggested by previous studies on high exposure settings [16,17,20,21,31,42,43].

However, as the mean seniority of the sample was relatively high (i.e., 10.4 \pm 3.4 years), it is possible that our results may be somehow affected by a significant "survivor bias." In other words, as our study included people who were able to maintain their jobs (i.e., healthy worker effect) and lost those who left the employment because of clinical conditions or other reasons, we may have ultimately underestimated the consequences of the zinc exposure [44]. In our sample, we identified an increased urinary excretion of zinc across both the working shift and the working week. Despite this increase was not statistically significant, the differential excretion was apparently well-correlated with personal exposure data. Our results are therefore consistent with the hypothesis that the respiratory tract is able to absorb zinc following inhalation $[1,14,16,17,20,21,24,29,40]$.

In this regard, both experimental and field studies suggest that zinc and zinc oxide are efficiently adsorbed by airborne dusts [45,46]: impacting upper airways, 35\% to $80 \%$ of zinc-enriched particles would be retained, swallowed and eventually absorbed through the gastrointestinal tract, the absorption rate of which would depend on the nutritional status, ranging between $8 \%$ and $80 \%$ $[1,14,16,17,20,21,31,45]$. As environmental sampling identified an airborne concentration of $1.58 \pm 0.34 \mathrm{mg} / \mathrm{m}^{3}$ for dusts having aerodynamic diameter $<10 \mu \mathrm{m}$, a significant role for this exposure route may therefore be supposed. Despite animal studies on $\mathrm{ZnO}$ fumes that collectively suggest that a rapid and transient increase of serum zinc may follow the exposure $[45,46]$, we have been unable to identify either such post-exposure peak or any correlation with the external exposures, as it was the case with some previous occupational studies $[14,29,31]$. These results may found several speculative explanations.

First at all, although Hollinger et al. [47] identified increased serum zinc levels in animals, it lasted only until $4 \mathrm{~h}$ after the end of the exposure. As blood samples, both in this survey and in some previous studies [14,29,31], were collected at the end of the first working shift (i.e., about $7 \mathrm{~h}$ after the beginning of exposure), it is possible that we simply failed to appropriately catch up the serum zinc peak. In this regard, it should be recalled that total zinc content in human body is subject to a strict and efficient homeo- 
static control: zinc has been identified as cofactor to more than 300 enzymes, but free $\mathrm{Zn}^{2+}$ ions are potentially toxic, and the redox-inert metallic $\mathrm{Zn}$ is involved in several signal transductions [15,48]. Serum zinc concentration should be therefore rather interpreted as a consequence of the dynamic equilibrium of absorbed zinc with body stores than a proxy of the actual exposure [1,14,24-26,29,31]. In effect, studies on gastrointestinal zinc absorption suggest that an increased oral exposure results in increased urinary excretion, as we have found in our survey $[16,17]$.

In other words, even the relatively low amount of zinc absorbed through both respiratory and gastrointestinal system in a setting of reduced occupational exposure may eventually result in transient high serum zinc concentration, that elicits an increased urinary excretion in order to avoid an excessive increase of body stores. Unfortunately, there is no clear correlation between absorbed dose and excreted amount of zinc: its rate is dependent on both current and past intakes, probably in dynamic equilibrium with body stores [20,21,24-27].

However, several limitations within our study should be addressed.

Firstly, we collected a small study population by convenience sampling (i.e., all workers from the same zinc electrogalvaning plant), that may be not representative of female working population exposed to zinc and $\mathrm{ZnO}$ in present day settings, where low temperature plating bath are associated with reduced production of fumes and suspended particles $[3,4]$. Another critical issue is represented by the self-assessment of work-related symptoms, that may be affected by some uncertainties, as its dichotomous design (i.e., reported/ not reported) may not accurately describe the relevance of such disorders. Moreover, as patients may undermine work-related complaints in order to keep their job, our study has potentially underestimated the clinical consequences of occupational zinc exposure.

Finally, as blood samples require invasive procedures, and their use in occupational practice biomonitoring has been disputed [14,49-51], we have considered an appropriate approach to collect only one sample at the end of the first working shift of the working week, even though this assessment may be somehow inaccurate, lacking the crossshift assessment we would have otherwise performed for urinary excretion.

\section{CONCLUSIONS}

Our results provide some insights about zinc toxicokinetics for female subjects exposed to $\mathrm{Zn} / \mathrm{ZnO}$ in the present-day settings of low-temperature zinc electrogalvaning. Despite the environmental sampling reported values for airborne zinc and zinc compounds well below $1 \%$ of DFG limit, serum and urinary zinc levels were similar to previous reports in significantly higher levels of exposure, suggesting that airborne zinc absorption might be quite effective. However, as the zinc body burden is strictly controlled, an increased exposure is associated with adaptive increased urinary excretion, the finality of which is to avoid toxic effects associated with zinc accumulation, eventually impairing the reliability of serum zinc as exposure biomarker.

As conclusive remarks, we suggest that end shift urine zinc and differential excretion of urine zinc (end of shift vs. begin of shift), whether performed at the beginning of the working week or not, may be useful proxies for the effective exposure, also for female workers.

\section{REFERENCES}

1. Safty AE, Mahgoub KE, Helal S, Maksoud NA. Zinc toxicity among galvanization workers in the iron and steel industry. Ann N Y Acad Sci. 2008;1140:256-62, https://doi.org/10.1196/ annals.1454.007.

2. International Zinc Association. Annual report 2015 [Internet]. Brussels: The Association; 2015 [cited 2016 Aug 3]. Available from: http://www.zinc.org/wp-content/uploads/sites/ 4/2015/11/IZA_AR_2015_vF_Web.pdf.

3. Davis JR. Surface engineering for corrosion and wear resistance. London: Money Publishing; 2001. 
4. Winand R. Electrodeposition of zinc and zinc alloys. In: Schlesinger M, Paunovic M, editors. Modern electroplating. 5th ed. London: John Wiley \& Sons; 2010, https://doi. org/10.1002/9780470602638.

5. American Conference of Governmental Industrial Hygienists. TLVs ${ }^{\circledast}$ and BEI ${ }^{\oplus}$ : Threshold Limit Values for chemical substances and physical agents and Biological Exposure Indices. Cincinnati: The Conference; 2014.

6. German Research Foundation. List of MAK and BAT values 2015. Permanent senate commission for the investigation of health hazards of chemical compounds in the work area. Report No. 51. Weinheim: Wiley-VCH; 2015.

7. Yan Z, Xu L, Han J, Wu YJ, Wang W, Yao W, et al. Transcriptional and posttranscriptional regulation and endocytosis were involved in zinc oxide nanoparticle-induced interleukin-8 overexpression in human bronchial epithelial cells. Cell Biol Toxicol. 2014;30:79-88, https://doi.org/10.1007/ s10565-014-9270-9.

8. Sturgis CC, Drinker P, Thomson RM. Metal fume fever: I. Clinical observations on the effect of the experimental inhalation of zinc oxide by 2 apparently normal persons. J Ind Hyg. 1927;9:88-97.

9. Drinker P, Thomson RM, Finn JL. Metal fume fever: IV. Threshold doses of zinc oxide, preventive measures, and the chronic effects of repeated exposures. J Ind Hyg. 1927; 9:331-45.

10. Rohrs LC. Metal-fume fever from inhaling zinc oxide. AMA Arch Ind Health. 1957;16:42-7, https://doi.org/10. 1001/archinte.1957.00260070058005.

11. Malo JL, Malo J, Cartier A, Dolovich J. Acute lung rection due to zinc inhalation. Eur Resp J. 1990;6:111-4.

12. El-Zein M, Malo JL, Infante-Rivard C, Gautrin D. Prevalence and association of welding related systemic and respiratory symptoms in welders. Occup Environ Med. 2003;60:655-61, https://doi.org/10.1136/oem.60.9.655.

13. Vogelmeier C, König G, Bencze K, Fruhmann G. Pulmonary involvement in zinc fume fever. Chest. 1987;92:946-8, https://doi.org/10.1378/chest.92.5.946.
14. Martin CJ, Le XC, Guidotti TL, Yalcin S, Chum E, Audette RJ, et al. Zinc exposure in Chinese foundry workers. Am J Ind Med. 1999;35:574-80, https://doi.org/10.1002/ (SICI)1097-0274(199906)35:6<574::AID-AJIM4>3.0.CO;2-L.

15. Schroeder HA, Nason AP, Tipton IH, Balassa JJ. Essential trace metals in man: Zinc. Relation to environmental cadmium. J Chronic Dis. 1967;20:179-210, https://doi. org/10.1016/0021-9681(67)90002-1.

16. Wastney ME, Henkin RI. Development and application of a model for zinc metabolism in humans. Prog Food Nutr Sci. 1988;12:243-54.

17. Wastney ME, Aamodt RL, Rumble WF, Henkin RI. Kinetic analysis of zinc metabolism and its regulation in normal humans. Am J Physiol. 1986;251:398-408.

18. Miller LV, Hambidge KM, Naake VL, Hong Z, Westcott JL, Fennessey PV. Size of the zinc pools that exchange rapidly with plasma zinc in humans: Alternative techniques for measuring and relation to dietary zinc intake. J Nutr. 1994:124:268-76.

19. Chesters JK, Will M. Zinc transport protein in plasma. Br J Nutr. 1981;46:111-8, https://doi.org/10.1079/BJN19810014.

20. King JC, Shames DM, Lowe NM, Woodhouse LR, Sutherland B, Abrams SA, et al. Effect of acute zinc depletion on zinc homeostasis and plasma zinc kinetics in men. Am J Clin Nutr. 2001;74:116-24.

21. King JC, Shames DM, Woodhouse LR. Zinc homeostasis in humans. J Nutr. 2000;130:1360-6.

22. Società Italiana Valori di Riferimento (Italian Society for Reference Values). [Third list for reference values of elements, organic compounds, and their metabolites] [Internet]. Siena: Società Italiana Valori di Riferimento / Laboratorio di Sanità Pubblica Area Vasta Toscana Sud-Est; 2011 [cited 2017 Aug 3]. Avalaible from: http://associazione. squarespace.com/pubblico. Italian.

23. Alimonti A, Bocca B, Mannella E, Petrucci F, Zennaro F, Cotichini R, et al. Assessment of reference values for selected elements in healthy urban population. Ann Ist Super Sanità. 2005;41:181-7. 
24. Giroux EL, Durieux M, Schechter PJ. A study of zinc distribution in human serum. Bioinorg Chem. 1976;5:211-8, https://doi.org/10.1016/S0006-3061(00)82019-0.

25. Schechter PJ, Giroux EL, Schlienger JL, Hoenig V, Sjoerdsma A. Distribution of serum zinc between albumin and $\alpha^{2}$-macroglobulin in patients with decompensated hepatic cirrhosis. Eur J Clin Invest. 1976;6:147-50, https://doi. org/10.1111/j.1365-2362.1976.tb00505.x.

26. Elinder CG, Kjellström T, Linnman L, Pershagen G. Urinary excretion of cadmium and zinc among persons from Sweden. Environ Res. 1978;15:474-84, https://doi.org/10. 1016/0013-9351(78)90126-3.

27. Costello LC, Fenselau CC, Franklin EB. Evidence for operation of the direct zinc ligand exchange mechanism for trafficking transport, and reactivity of zinc in mammalian cells. J Inorg Biochem. 2011;105:589-99, https://doi.org/10.1016/ j.jinorgbio.2011.02.002.

28. Drinker K, Drinker P. Metal fume fever: V. Results of the inhalation by animals of zinc and magnesium oxide fumes. J Ind Hyg. 1928;10:56-70.

29. Hamdi EA. Chronic exposure to zinc of furnace operators in a brass foundry. Br J Ind Med. 1969;26:126-34, https:/doi. org/10.1136/oem.26.2.126.

30. Blanc P, Wong H, Bernstein MS, Boushey HA. An experimental human model of metal fume fever. Ann Intern Med.1991;114:930-6,https://doi.org/10.7326/0003-4819-11411-930.

31. German Research Foundation. Zinc and its inorganic compounds. Weinheim: Wiley-VCH; 2014.

32. Arrandale VH, Beach J, Cembrowski GS, Cherry NM. Urinary metal concentrations among female welders. Ann Occup Hyg. 2015;59:52-61, https://doi.org/10.1093/annhyg/ meu079.

33. Brille D, van der Lende R, Sanna-Randaccio F, Smidt U, editors. Notes on the ECSC-questionnaire for studying chronic bronchitis and pulmonary emphysema (1967) produced under the auspices of the Research Commission on "Chronic Respiratory Diseases" by an ad hoc working group "Epidemiology of Chronic Bronchitis". Luxemburg: Commission of the European Communities, Industrial Hygiene and Medicine Texts; 1973.

34. Redlich CA, Tarlo SM, Hankinson JL, Townsend MC, Eschenbacher WL, von Essen SG, et al. Official American Thoracic Society technical standards: Spirometry in the occupational setting. Am J Respir Crit Care Med. 2014;189: 983-93, https://doi.org/10.1164/rccm.201402-0337ST.

35. Quanjer PH. Standardized lung function testing. Bull Eur Physiopathol Respir. 1983;19(S5):1-95.

36. Quanjer PH, Tammeling GJ, Cotes JE, Pedersen OF, Peslin R, Yernault JC. Lung volumes and forced ventilatory flows. Eur Respir J. 1993;6 Suppl. 16:5-40. Erratum in: Eur Respir J. 1995;8:1629.

37. Occupational Safety and Health Adminsitration [Internet]. Washington: The Administration; 2002 [cited 2016 Aug 2]. Metal \& metalloid particulates in workplace atmospheres (atomic absorption). Available from: http://www.osha.gov/ dts/sltc/methods/inorganic/id121/id121.html.

38. Friedman M. The use of ranks to avoid the assumption of normality implicit in the analysis of variance. J Am Stat Assoc. 1937;32:675-701, https://doi.org/10.1080/01621459.1937. 10503522.

39. [The Act No. 81 of 9 April 2008 on health and safety in the workplaces. J Laws (GU) 2008, No. 101, ordinary suppl. No. 108]. Italian.

40. Knecht U, Borris D, Tiller R, Haeder M, Woitowitz H-J. Welding and grinding work on zinc plated or zinc coated car body metals: Inhalation/exposure and biomonitoring. In: Report on the 23rd annual meeting of the German Society for Occupational Medicine, the Association of German Physicians in Industry and Administration, German Professional Medical Association, and the Organization of Occupational Industrial Insurance Societies. Stuttgart: Gentner Verlag; 1983. p. 497-504.

41. Cirla AM, Zedda S. Assessment of the risk in thermal zincification factories: Monitoring of employees. Ann Ist Super Sanita. 1981;17:465-9. 
42. Aminiam O, Zeinodin H, Sadeghniiat-Haghighi K, Izadi N. Respiratory symptoms and pulmonary function tests among galvanized workers exposed to zinc oxide. J Res Health Sci. 2015;15:159-62.

43. Sala C, Ciullo M, Lanzara C, Nutile T, Bione S, Massacane R, et al. Variation of hemoglobin levels in normal Italian populations from genetic isolates. Haematologica. 2008;93: 1372-5, https://doi.org/10.3324/haematol.12915.

44. Signorelli C, Riccò M, Vinceti M. [Waste incinerator and human health: A state-of-the-art review]. Ann Ig. 2008;20: 251-77. Italian.

45. Beckett WS, Chalupa DF, Pauly-Brown A, Speers DM, Stewart JC, Frampton MW, et al. Comparing inhaled ultrafine versus fine zinc oxide particles in healthy adults. Am J Respir Crit Care. 2005;171:1129-35, https://doi.org/10. 1164/rccm.200406-8370C.

46. Cohen HJ, Powers BJ. Particle size characterizations of copper and zinc oxide exposures of employees working in a nonferrous foundry using cascade impactors. Am Ind Hyg Assoc J. 2000;61:422-30, https://doi.org/10.1080/15298660008 984554.
47. Hollinger MA, Raabe OG, Giri SN, Freywald M, Teague SV, Tarkington B. Effect of the inhalation of zinc and dietary zinc on paraquat toxicity in the rat. Toxicol Appl Pharmacol. 1979;49:53-61, https://doi.org/10.1016/0041-008X(79) 90276-X.

48. Chasapis CT, Loutsidou AC, Spiliopoulou CA, Stefanidou ME. Zinc and human health: An update. Arch Toxicol. 2011;86:521-34, https://doi.org/10.1007/s00204-011-0775-1.

49. Manzoli L, Sotgiu G, Magnavita N, Durando P. National Working Group on Occupational Hygiene of the Italian Society of Hygiene, Preventive Medicine and Public Health (SItI). Evidence-based approach for continuous improvement of occupational health. Epidemiol Prev. 2015; 39:S81-5.

50. Signorelli C, Riccò M, Odone A. The Italian National Health Service expenditure on workplace prevention and safety (2006-2013): A national-level analysis. Ann Ig 2016;28: 313-8, https://doi.org/10.7416/ai.2016.2111.

51. Signorelli C, Riccò M. [The health-environment interaction in Italy]. Ig Sanita Pubbl 2012;68:374-80. Italian.

This work is available in Open Access model and licensed under a Creative Commons Attribution-NonCommercial 3.0 Poland License - http://creativecommons.org/ licenses/by-nc/3.0/pl/deed.en. 